\title{
Carbon Emissions in Recreation Fishing Travelling. Case of Latvia
}

\author{
Tamara GRIZANE ${ }^{1 *}$, Dagnija BLUMBERGA ${ }^{2}$ \\ ${ }^{1,2}$ Institute of Energy Systems and Environment, Riga Technical University, 12-k1 Äzenes street, \\ Riga, LV-1048, Latvia
}

\begin{abstract}
The tourism industry holds high importance for the economy of Latvia; therefore, it is important to comply with the low-emission mobility strategy. The aim of this research is to investigate the $\mathrm{CO}_{2}$ emissions caused by a trip to Latvia's Western coast at the Baltic Sea for recreational fishing in order to create information basis for intensifying the development of the specific tourism industry on a Baltic Sea states scope. In this research a hybrid (topdown and bottom up) and regression method was used for determination of $\mathrm{CO}_{2}$ emissions and interlinked relations. Research results: Altogether travelling forth and back to fishing destinations totalled $22546 \mathrm{~km}$, emitting $5.796 \mathrm{tCO}_{2}$ emissions; vehicle occupation rates for vehicles vary - for car $-\mathbf{2 8 . 9} \%$, for motorhome $-\mathbf{5 0} \%$, for vans $-\mathbf{2 5} \%$. Renewal of car fleet to more fuel-economy vehicles would help comply with the $\mathrm{CO}_{2} 95 \mathrm{~g} / \mathrm{km}$ goal, would reduce the emissions by $684.49 \mathrm{~kg}, 847 \mathrm{~kg}$ and by $570.84 \mathrm{~kg}$ accordingly. The emission reduction per passenger with $60 \%$ seat occupancy depend on the car $\mathrm{CO}_{2}$ emission ratio $155 \mathrm{~g} / \mathrm{km}, 147 \mathrm{~g} / \mathrm{km}$ or $131 \mathrm{~g} / \mathrm{km}$, and would correspond to the cumulative effect of $\mathrm{CO}_{2}$ $6.77 \mathrm{~kg}, 5.01 \mathrm{~kg}$ and $5.40 \mathrm{~kg}$. Annual journey to fishing destinations per passenger, with $95 \mathrm{~g} / \mathrm{km}$ emissions and $60 \%$ vehicle occupancy rate with given registered $\mathrm{CO}_{2}$ emissions at $155 \mathrm{~g} / \mathrm{km}, 147 \mathrm{~g} / \mathrm{km}$ or $131 \mathrm{~g} / \mathrm{km}$ : would produce $\mathrm{CO}_{2} 297.7 \mathrm{~kg}, 322.7 \mathrm{~kg}$ and $280.2 \mathrm{~kg}$ accordingly. Use of seat-sharing of newer cars would allow for a reduction of emissions, specifically within Latvia's Western coast of Baltic Sea recreation fishing area, where due to the scarce population, public transport is less available.
\end{abstract}

Keywords - $\mathrm{CO}_{2}$ emissions; transportation; recreation fishing

\section{INTRODUCTION}

Considering the fact that travel to certain destinations is a predefined part of tourism per se, the tourism industry utilizes passenger transport services. According to the European Environment Agency (EEA), tourism contributes in large part to the increase of pollution via means of transport. Thus, tourism can be attributed to being one of the antropogenous component drivers of global warming [1]. Tourism is intertwined with the transportation sector, which globally accounts for $21 \%$ of all anthropogenic $\mathrm{CO}_{2}$ emissions [2]. According to the European low-emission mobility strategy, the goal is to reduce emissions until 2050 compared to 1990 by at least $60 \%$ [3]. Due to the impact of Covid-19 pandemic on tourism sector and the overall economy, the use of transport has decreased and thus it is a suitable time to reset the current approach to mobility.

In 2018 the EU28 emitted $3.5 \mathrm{Gt} \mathrm{CO}_{2}$, corresponding to $6.8 \mathrm{t} \mathrm{CO}_{2}$ rate per person [4]. In comparison to such Baltic Sea states as Estonia (EST), Lithuania (LT), Finland (FI) and

* Tamara Grizane

E-mail address: tamara.grizane@inbox.lv 
Sweden (SW), as well as the EU-28 average in 2018 Latvia's fossil $\mathrm{CO}_{2}$ emission rate was lower than that of Sweden. This has happened despite of the fact that the economy of Latvia has had multiple crises and the country's economic recovery often is stemmed with the use of investments in infrastructure which is related to a more intense $\mathrm{CO}_{2}$ emission (Fig. 1).

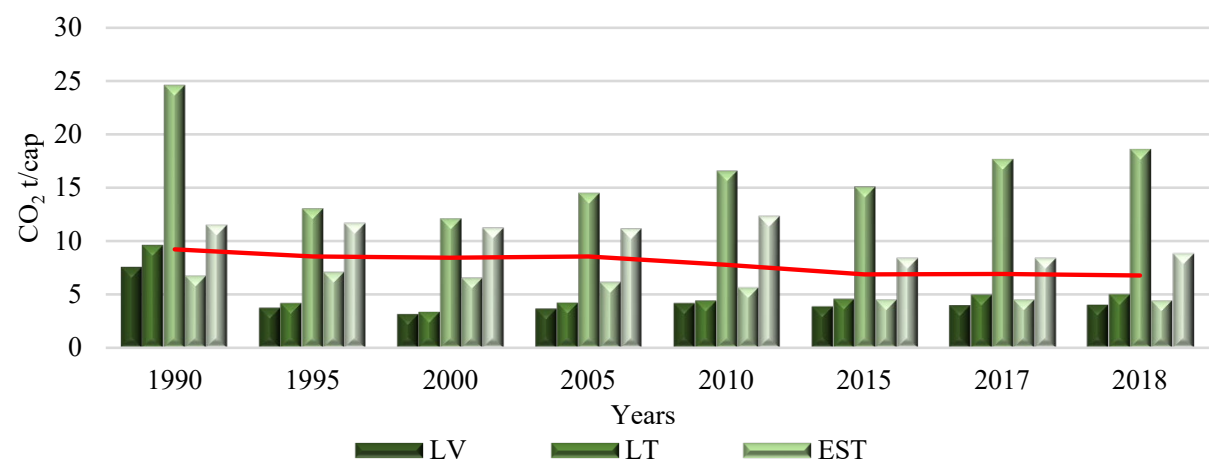

Fig. 1. Fossil $\mathrm{CO}_{2}$ per capita emissions, $\mathrm{CO}_{2} \mathrm{t} / \mathrm{cap}[4]$.

The tourism sector is expanding as indicated by the increased number of foreign travellers; e.g., in 2018 in comparison with 2007 the total number has increased by 2.5 million and on average (2007 through to 2018) was 5.58 million persons; [5] the number of inland travellers - increased by 76.5 thousand, on average (2015 through 2018) 1.3 million persons [6]. Meanwhile, the number of tourists to the Kurzeme region of Latvia, which is located along the coast of the Baltic Sea, has decreased by 377.1 thousand (2017-2018), which is disturbing in terms of a balanced regional growth. This is the largest drop of number of travellers in Latvia in all categories, except for the one-day travels, which has increased by 147 thousand [7]-[9]. Considering the Covid-19 impact on the tourism sector, the numbers of travellers for 2020 are expected to further decrease.

Analysis of the inland travel, including that of visits to the coast of Kurzeme region, shows (Fig. 2) that the length of stay does not impact the choice of transport, with majority choosing passenger car followed by bus. However, for the same-day trips, bus is slightly more popular than for overnight trips.

On the one hand, for the sake of economic growth, it is important to increase the number of travellers, while on the other hand $\mathrm{CO}_{2}$ emissions must be decreased. Some of the means for increasing the number of travellers is by extending tourism services in the niche of fishing tourism. The potential of this type of tourism has been underlined by Sweden, Finland, Estonia, Poland, Lithuania and Latvia, which have collectively turned to the analysis of its potential and promoting the fishing tourism in the Baltic Sea coastal regions. This is an opportunity to develop Kurzeme as a potential fishing tourism destination [10]. 


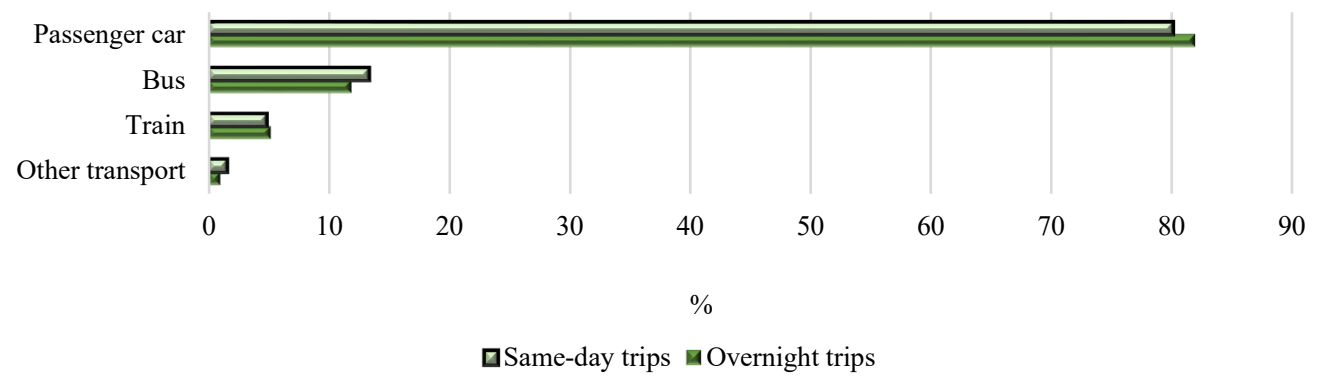

Fig. 2. Mode of transport used during overnight and same-day trips around Latvia 2018, \% [8], [9].

Transport to any destination target will accrue $\mathrm{CO}_{2}$ emissions. Meanwhile a paradox exists - although people understand the negative impact of global warming, it is difficult for some to draw a conclusion that their daily activities and $\mathrm{CO}_{2}$ emissions cause these global changes [11]. Are there any other means for reduction of $\mathrm{CO}_{2}$ emissions? These questions are asked by the scientists, when offering the use of different technological solutions: fuel decarbonisation (bio-fuel, electric cars), efficiency increasing car technology, choice of optimum travel speed, use of bicycle or choice to walk shorter distances [12]-[16].

The connection between transport and tourism is significantly strong in non-urban areas, because the predefinition of tourism defines that those are visits to areas which the traveller is not accustomed to go on a daily basis. It is more difficult to assess the emissions caused by tourism transport, because the available data is scarce. The $\mathrm{CO}_{2}$ emissions caused by tourism transport can be calculated by different means. When data on the number of travels and the average travelled distance are available one can calculate the current and future $\mathrm{CO}_{2}$ emissions for both the local and international tourist flow. For this purpose, carbon intensity coefficients by type of transport and region or $\mathrm{CO}_{2}$ emission calculators are used [17]. Often mixed methods are used in research, for instance, quantitative approach with on-road GPS data analysis, while the qualitative data is acquired from summaries of interviews, which augment and offer deeper understanding about the quantitative data [18].

More precise data is acquired on transport $\mathrm{CO}_{2}$ emissions when carrying out research focused on the type of transport, fuel consumption, average driven distance, bottom-up assessment method [19], [20].

More accurate results are acquired when assessing the emission amounts based on on-field benchmark analysis. It is important to define the result indicators and to avert the lack of knowledge, as well as to clearly show the benefits of adaptation methods and local-level vulnerability assessments.

The goal of this paper is to analyse the $\mathrm{CO}_{2}$ emissions caused by a trip to Latvia's Western coast of the Baltic Sea for recreational fishing purposes, in order to create part of the information basis upon which intensification of the development of this specific tourism industry on the scale of the Baltic Sea States area can be implemented. Primary data have been acquired during August (16.08-21.08) and October 2019 (25.10-26.10) and have been consolidated by interviewing 65 respondents during their fishing trips.

In order to fulfil the goals of the research, the following tasks were carried out:

1. Define the path to vocational fishing destination;

2. Analyse the choice of modes of transport for recreational tourism and passengers;

3. Define the $\mathrm{CO}_{2}$ emissions created over the path to the destination; 
4. Define the average vehicle rates occupancy;

5. Carry out $\mathrm{CO}_{2}$ emissions scenarios and analyse the results.

The methods applied: in order to assess and reduce the emissions caused by the transportation of tourists over the path to the fishing destination in the Kurzeme region on the Baltic sea shore, a hybrid (top-down and bottom up) and regression method was used connections between the path distance and $\mathrm{CO}_{2}$ emissions caused by the vehicle were analysed, along with a method of analyses and synthesis were used in the research.

\section{GUidelines for MaNuSCRIPT Preparation}

\subsection{Case Study Site}

The case study site is the western coastline of the Baltic Sea, which is located in the Kurzeme region. Within the Kurzeme region of Latvia, this includes the Baltic Sea coast from Pape to the Irbe river delta, the mainland area stretches to the lakes Pape, Liepaja, Durbe, Tasu and Usma (Fig. 3). According to Eurostat, coastline municipalities are entities that have territories with a coastline to the sea, or where the largest part lies within $10 \mathrm{~km}$ distance from the sea [21] Eurostat (2017).
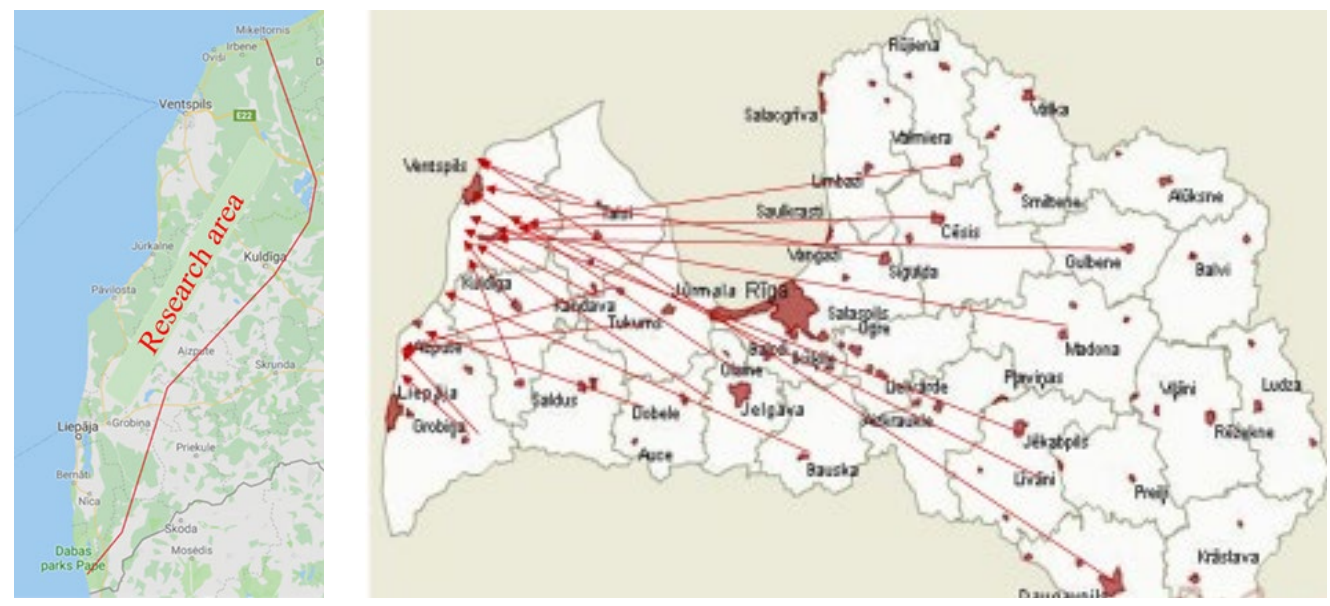

Fig. 3. Research area and place of residents of respondents.

\subsection{Study Approach}

This study used a mixed method (by Bryman) and a top-down and bottom-up technique to measure $\mathrm{CO}_{2}$ emissions from recreational fishing destinations [22], [23].

The respondent survey $(n=65)$ was carried out in 2019 in five most-suitable days for fishing in August and September. The place and time of the survey was chosen, based on the information published by fishing enthusiasts on the webpage: https://www.copeslietas.lv/. Data were analysed using a statistical computer program and interpreted as follow:

- First step: Define the path of fishing tourists on their way to their destination;

- Second step: Analyse the choice of modes of transport for recreational tourism and passengers;

- Third step: Define the $\mathrm{CO}_{2}$ emissions on the path to fishing destination; 
- Fourth step: Estimate the average vehicle rate occupancy;

- Fifth step: Define $\mathrm{CO}_{2}$ emissions scenarios and analysis of results.

\subsubsection{First Step: Definition of the Path of Fishing Tourists on Their Way to Their Destination}

Respondents were surveyed in 14 destinations: Durbe lake, Pape lake and channel, Puze lake and Usma lake, as well as in other popular locations on the coastline regions, for instance, Jurkalne, Jurmalciems, Liepāja (Southern and Northern pier), Luzņa, Mikeltornis and Mikelbaka (both consolidated under title of Mikeltornis), Ovisi, Pavilosta, Pitrags, Uzava and Ventspils (Southern and Northern pier and promenade). The concentration of fishermen depends on climate factors (wind speed, temperature, sea streams, that define the occurrence of seaweed, fish shoals and daytime. Authors noticed that all these factors had an impact on the number of visits by the vocational fishermen. The distance was monitored with the use of the web tool Google Maps. For the local fishing enthusiasts, it was assumed that the average path to fishing destinations by foot was 5 kilometres. The total distance was estimated as double the way to and the way back. The time that respondents covered by boat, was not included due to statistical data availability reasons. Thus, this study has not included recreational fishing that is conducted by tourists arriving to the fishing area by boat.

\subsubsection{Second Step: Analysis of the Choice of Modes of Transport for Recreation Tourism and Passengers}

The respondents shared information on their means of travelling to the fishing destination: car brand and first year of registration. Of the groups of visitors to the recreation fishing sites only those travellers were surveyed who personally were fishing, while the rest of co-travellers were included in the general statistics. Further analysis did not include types of transport which are $\mathrm{CO}_{2}$ neutral (walking, row or sail boat), piston-engine vehicles on which there is no statistical data available, modes of transport that cannot be used for travelling significantly increased distances (i.e. cycling).

\subsubsection{Third Step: Definition of $\mathrm{CO}_{2}$ Emissions En-Route to the Fishing Destination}

The $\mathrm{CO}_{2}$ emissions were defined according to the Road Traffic Safety Directorate of Lavia (RTSD) manual on $\mathrm{CO}_{2}$ emissions $(\mathrm{g} / \mathrm{km})$ caused by cars available in 2018 and 2019 as well as the $\%$ of registered passenger cars based on the year of registration in Latvia based on $\mathrm{CO}_{2}$ emissions by 01.01 .2019 [24] (Fig. 4).

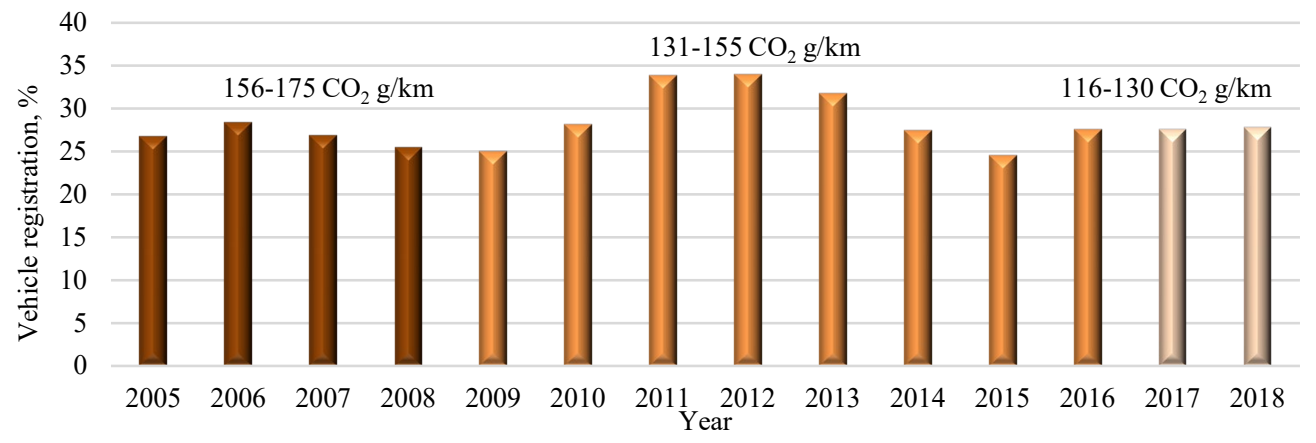

Fig. 4. Registered vehicles \% by year in Latvia according to $\mathrm{CO}_{2}$ emissions by 01.01.2019 [22]. 
According to provisional data, the average EU emissions level of the new cars registered in

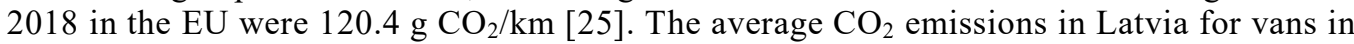
2012 were estimated as $176.9 \mathrm{CO}_{2} \mathrm{~g} / \mathrm{km}$ and according to provisional data, the average emissions of new vans registered in 2018 were $158.1 \mathrm{~g} \mathrm{CO}_{2} / \mathrm{km}$ [26]. The $\mathrm{CO}_{2}$ emissions for motorhomes were defined $307 \mathrm{CO}_{2} \mathrm{~g} / \mathrm{km}$ [27]. The average $\mathrm{CO}_{2}$ emissions for buses are $170 \mathrm{~g} \mathrm{CO}_{2} / \mathrm{km}$, and this indicator was used, based on the data from UK Defra [28].

The $\mathrm{CO}_{2}$ emissions of transport towards fishing destinations (two-way) - in the western part of Kurzeme region of Latvia by the eastern shore of the Baltic Sea according following Eq. (1):

$$
C O_{2}=\sum_{k=1}^{n} A_{n} \cdot 2 d_{n},
$$

where

$\mathrm{CO}_{2} \quad$ Total emissions, $\mathrm{g} / \mathrm{km}$;

$A_{n} \quad$ Emissions of $n$-car;

$d_{n} \quad$ Travelled distance by car, one way, $\mathrm{km}$.

\subsubsection{Fourth Step: Estimation of the Average Vehicle Rates Occupancy}

The car occupancy defines the average number of people transported with a vehicle and the maximum number of persons transported. The declared occupancy levels are based on publications and the mobility issues [29]-[31].

The car occupancy is calculated based on the method that can be found in literature, the DRIEA Direction régionale et interdépartementale de l'Équipement et de l'Aménagement) (Regional and interdepartmental Department of Equipment and Planning) method defined the occupancy as the total number of declared voyages (as driver and passenger) against the number of voyages where only the driver has been registered [32]. The variables are connected to private household travel and their goals require a different view on transport occupancy, as well as the cases, when the examples are connected with the travel regularity, seasonality, travel activities, etc. [33], [34] Taking into account the goal of recreation fishing in this study this phenomena has been viewed as a one-time occurrence, the authors use a method where the vehicle occupancy rate for passenger cars is calculated as average number of passengers in a vehicle (cars, buses, trains, aircraft) [35], i.e. the following Eq. (2):

$$
A V O_{\mathrm{veh} 1}=\sum_{k=1}^{n} \frac{R P_{n}}{v^{e} h_{n}}
$$

where
$A V O_{\text {veh1 }}$
$R P_{n}$
$v h_{n}$
Average occupancy rate (with driver) per vehicle, passenger/car; $n$ real number of passengers (with driver); $n$ number of vehicles.

Correspondingly, the average number of passengers of travel with a motorhome and van were calculated. Considering the fact that during this survey there were no recorded cases of visitors using public transport (bus) and that there are no general assumptions on their possible numbers; this data was not taken into consideration when calculating the vehicle occupancy rate. 
In order to define the average number of transported persons per vehicle according to the maximum possible number of people, which can be transported, the following Eq. (3) was used:

$$
A V O_{\text {veh } 2}=\sum_{k=1}^{n} \frac{\frac{R P_{n}}{v e h_{n}}}{\frac{\operatorname{veh}_{n}}{\operatorname{vax} P_{n}}} \cdot 100
$$

where

$$
\begin{array}{ll}
A V O_{\text {veh2 }} & \text { Average occupancy rate - average number of passengers (with driver) per } \\
& \text { vehicle, \%; } \\
R P_{n} & n \text { real number of passengers (with driver); } \\
v e h_{n} & n \text { number of vehicles; } \\
\max _{n} & n \text { maximum number of passengers (with driver) in the vehicle. }
\end{array}
$$

Since there were no respondents commuting with public transport, due to lack of information on this number, it was not possible to calculate the real number of destinations' visitors and the average vehicle occupancy rate in absolute numbers, but only in percentage.

\subsubsection{Fifth Step: Definition of $\mathrm{CO}_{2}$ Emissions Scenarios and Analysis of Results}

Based on acquired information, the transport emissions forecast allows to choose the optimum approach for minimizing the $\mathrm{CO}_{2}$ emissions [36]. Considering the results of the research and main conclusions about recreational fishing trip and destination, a given set of scenarios for reduction of carbon emissions was drafted.

Based on these conclusions, authors propose three scenarios:

- First scenario - replacing the current light weight vehicles with newer ones, which are in line with EU regulations at $95 \mathrm{gCO}_{2} / \mathrm{km}$.

- Second scenario - the light vehicle (car) occupancy rate reaches the peak at $100 \%$ and $60 \%$.

- Third scenario - recreational fishing trip with $\mathrm{CO}_{2}$ emissions for cars at $95 \mathrm{gCO} / \mathrm{km}$ with $60 \%$ average vehicle occupancy rate.

The scenarios will help to answer the following questions:

- By what amount would the $\mathrm{CO}_{2}$ emissions decrease if the respondents would use new transport vehicles, according to EU Regulation (EU) 2019/631 from 2020 [37], when the EU fleet-wide average emission target for new cars will be $95 \mathrm{gCO}_{2} / \mathrm{km}$ ?

- By what amount would the $\mathrm{CO}_{2}$ emissions be reduced per one passenger if $100 \%$ or $60 \%$ of the seats would be occupied?

- By what amount would the $\mathrm{CO}_{2}$ emissions be reduced per passenger when travelling to the recreational fishing destinations per year, compared to the values estimated within the research, if cars with $95 \mathrm{gCO}_{2} / \mathrm{km}$ and $60 \%$ average occupancy rate would be used?

The scenario data was based on the European Commission Regulation for reducing $\mathrm{CO}_{2}$ emissions from passenger cars. 


\section{Results AND DiscuSSION}

\subsection{Determination of Travel Route to Fishing Destination}

The information on visitors by place of residence allows to calculate the distance travelled to the fishing destination $-20 \%$ of respondents travelled from Riga, $13.8 \%$ from Ventspils, $7.7 \%$ from Ogre, $6.2 \%$ from Tukums and Liepaja each, $4.6 \%$ from Talsi and Cesis each, $3.1 \%$ from Durbe, but others from Aizpute, Bauska, Kandava, Kuldīga, Limbazi, Pope, Smiltene and Valmiera. From locations in Lithuania - Akmene, Kaunas, Klaipeda, Siauliai and Telsai - altogether seven respondents. The Baltic coast in Kurzeme was visited also by visitors from Munich and Hannover (Germany) while travelling $1756 \mathrm{~km}$ and $1513 \mathrm{~km}$ distance correspondingly which had been travelling to the Kurzeme by land routes exclusively. The furthest inland respondents came from Smiltene - $326 \mathrm{~km}$, Valmiera $315 \mathrm{~km}$ and Cesis - $309 \mathrm{~km}$. Respondents altogether, when travelling to the fishing destinations and returning home, had driven $22546 \mathrm{~km}$, but, on average, each had driven $346.86 \mathrm{~km}$.

As part of determining recreational fishing destinations, 14 locations were visited (Table 1). Among these the most visited destinations with highest fishermen number within Latvia's Western coast of the Baltic Sea were the coast at Mikeltornis and Uzava.

TABLE 1. RESPONDENTS RECREATIONAL FISHING PlaCES ON LATVIA'S WESTERN COAST OF THE BALTIC SEA

\begin{tabular}{llllll}
\hline $\begin{array}{l}\text { Place of } \\
\text { recreational fishing }\end{array}$ & Frequency & Percent & Recreational fishing & Frequency & Percent \\
\hline Durbes lake & 2 & 3.1 & Papes lake, channel & 8 & 12.3 \\
Jurkalne & 1 & 1.5 & Pavilosta & 4 & 6.2 \\
Jurmalciems & 1 & 1.5 & Pitrags & 1 & 1.5 \\
Liepaja & 7 & 10.8 & Puzes lake & 1 & 1.5 \\
Luzna & 8 & 12.3 & Usmas lake & 6 & 9.2 \\
Mikeltornis & 14 & 21.5 & Uzava & 7 & 10.8 \\
Ovisi & 1 & 1.5 & Ventspils & 4 & 6.2 \\
\hline
\end{tabular}

\subsection{Analysis of the Choice of Modes of Transport and Movement for Recreation Tourism}

Of 65 respondents (Table 2.), 45 drove 11 different brand cars, two with motorhomes, and one with a van and one by boat, three commuted by bus and two were fishermen-passengers, while the rest of the passengers were family members who were not engaged in recreational fishing.

The impact of the transport sector on $\mathrm{CO}_{2}$ emissions of the transport sectors for reaching tourism destinations was dependant on different factors, including, number of persons that travel with a given vehicle [38].

The Audi brand cars were the most popular with $19.05 \%$ (Table 2). This estimation matches the information from CSDD statistics that indicate Audi as the most popular brand of car in Latvia.

The second most popular car brand used for travelling is Nissan $-9.52 \%$ and Honda $7.94 \%$. When comparing the types of transport used for reaching the destination (Table 2.), in $73 \%$ of the cases, light vehicles were used. Meanwhile in the case of recreational fishing participants from the cities of Liepaja and Ventspils and their suburban areas - pedestrians 
were $14.29 \%$. The surveyed tourists from Germany used a motorhome for their trip, and vans were used by two families from Latvia.

One of the travellers had arrived with the help of a paddle boat, another with a bicycle, while remaining three had commuted by bus.

TABLE 2. CHOICE OF TYPE OF TRANSPORT FOR REACHING RECREATIONAL FISHING DESTINATIONS ON THE WESTERn PART OF LATVIA's COAST OF THE BALTIC SEA

\begin{tabular}{llllll}
\hline $\begin{array}{l}\text { Modes of transport } \\
\text { and movement }\end{array}$ & Frequency & Percent & $\begin{array}{l}\text { Modes of transport and } \\
\text { movement }\end{array}$ & Frequency & Percent \\
\hline AUDI & 12 & 19.05 & VW & 2 & 3.17 \\
FORD & 2 & 3.17 & MITSUBISHI & 3 & 4.76 \\
HONDA & 5 & 7.94 & Motorhome & 2 & 3.17 \\
HYUNDAI & 3 & 4.76 & Walking & 9 & 14.29 \\
MAZDA & 2 & 3.17 & Cycling & 1 & 1.59 \\
NISSAN & 6 & 9.52 & Bus & 2 & 4.47 \\
OPEL & 4 & 6.35 & Paddle boat* & 1 & 1.59 \\
SKODA & 4 & 6.35 & Vans & 1 & 1.59 \\
TOYOTA & 3 & 4.76 & & & \\
\hline
\end{tabular}

* further information on the use of the particular type of vehicles is unavailable due to lack of statistical data

The analysis of the cars used for travelling the distance to the destination show that $37.8 \%$ of the cars were registered for the first time in Latvia in 2005-2006, 11.1\% in 2016-2017, while the rest from 2007 till 2015.

\subsection{Estimation of $\mathrm{CO}_{2}$ Emissions to Recreational Fishing Destination}

The registration year of the car brands used for travelling to the destinations are connected to the amount of $\mathrm{CO}_{2}$ emissions. The newer the car, the less emissions it produces compared to a previous model (Table 3), however, the specifics of Latvia in terms of new cars should be considered. The statistical data show that until 2019, the average age of light transport was 16 years, a fact that proved correct within the research. In the meantime, the EU average age of cars was 11 years. In UK it was 7.8 years, but in Austria and Switzerland 8.2 and 8.6 years correspondingly [39].

TABLE 3. $\mathrm{CO}_{2}$ EMISSIONS FROM PASSENGER CARS OF RECREATIONAL FISHING ON LATVIA'S WESTERn COAST OF THE BALTIC SEA

\begin{tabular}{llclll}
\hline $\begin{array}{l}\text { Type of } \\
\text { transport }\end{array}$ & $\begin{array}{l}\text { Year of } \\
\text { Registration } \\
\text { (number of cars) }\end{array}$ & $\begin{array}{l}\text { Emissions per } \\
\mathbf{k m}, \mathbf{g} / \mathbf{k m}\end{array}$ & $\begin{array}{l}\text { Emissions on a } \\
\text { trip (156 g/km), }\end{array}$ & $\begin{array}{l}\text { Emissions on a trip } \\
(\mathbf{1 7 5} \mathbf{g} / \mathbf{k m}), \mathbf{g}\end{array}$ & $\begin{array}{l}\text { Total emissions } \\
\text { per journey, } \mathbf{g}\end{array}$ \\
\hline & $2006-2007(20)$ & $156-175$ & 656292 & 719688 & 1375980 \\
Cars & $2009-2016(21)$ & $131-155$ & 887944 & 1050621 & 1938565 \\
& $2017-2018(1)$ & $116-130$ & 181656 & 20358 & 202014 \\
\hline
\end{tabular}

The relationship between the year of registration and emissions can be seen in Table 3 . In 2009-2016 registration vehicles account for $51.1 \%$ of all cars, 2006-2007-37.8 \%, of the light vehicles, but the $\mathrm{CO}_{2}$ emissions for the first were only $231.652-330.933 \mathrm{~kg}$ larger. The 
$2020 / 24$

emissions for a motorhome had a high emission index per one $\mathrm{km}$ and it as utilised for longhaul travel, reaching a $2007.166 \mathrm{CO}_{2} \mathrm{~kg}$ emissions, which is close to of the total emissions from the light transport vehicles (Table 4.).

Therefore, the $\mathrm{CO}_{2}$ emissions per one $\mathrm{km}$ and thus the total trip emissions were connected to the type and age of transport vehicle (Table 3.). Altogether the vehicles spent for driving forth and back $22546 \mathrm{~km}$, splitting $5795.912 \mathrm{~kg}$ or $5.796 \mathrm{t} \mathrm{CO}_{2}$ emissions (Table 4).

TABLE 4. MOTORHOME, BuS AND VANS $\mathrm{CO}_{2}$ EMISSIONS FROM RECREATIONAL FISHING ON LATVIA'S WESTERN COAST OF THE BALTIC SEA

\begin{tabular}{lll}
\hline Type of transport & $\mathbf{C O}_{2}$ emissions per $\mathbf{k m}, \mathbf{g} / \mathbf{k m}$ & $\mathbf{C O}_{2}$ emissions per trip, $\mathbf{k g}$ \\
\hline Car & $116-156$ & 3516.559 \\
Motorhome & 307 & 2007.166 \\
Bus & 170 & 243.950 \\
Van & 187 & 28.237 \\
Total & - & $\mathbf{5 7 9 5 . 9 1 2}$ \\
\hline
\end{tabular}

For a more detailed analysis of the $\mathrm{CO}_{2}$ emissions produced during a journey to a recreational fishing destination, the authors chose cars registered in the period 2009-2016 as the largest group by type of transport with the highest $\mathrm{CO}_{2}$ emissions (Table 5).

TABLE 5. DesCRIPTIVE StATISTICS ON $\mathrm{CO}_{2}$ EMISSIONS AND TRIPS

\begin{tabular}{llll}
\hline & Trip, $\mathbf{k m}$ & Emissions, $\mathbf{C O}_{\mathbf{2}} \mathbf{1 3 1} \mathbf{~ k g} / \mathbf{k m}$ & Emissions, $\mathbf{C O}_{\mathbf{2}} \mathbf{1 5 5} \mathbf{~ k g} / \mathbf{k m}$ \\
\hline Number & 21 & 21 & 21 \\
Mean & 322.77 & 42.28 & 50.03 \\
Median & 332.00 & 43.49 & 50.03 \\
Std. Deviation & 184.065 & 24.113 & 28.530 \\
Minimum & 10 & & \\
Maximum & 652 & & \\
\hline
\end{tabular}

The relationship between the trip distance and $\mathrm{CO}_{2}$ emissions in $\mathrm{CO}_{2} 131 \mathrm{~g} / \mathrm{km}$ and $\mathrm{CO}_{2} 155 \mathrm{~g} / \mathrm{km}$ scenarios can be visualized, which portray the output of the cars registered within the 2009-2016 period and which were the most commonly used within the research scope. The data were determined with a correlation method and were included as a scatter diagram, which allows to visually determine a positive linear connection between both sig. values (Fig. 5). 


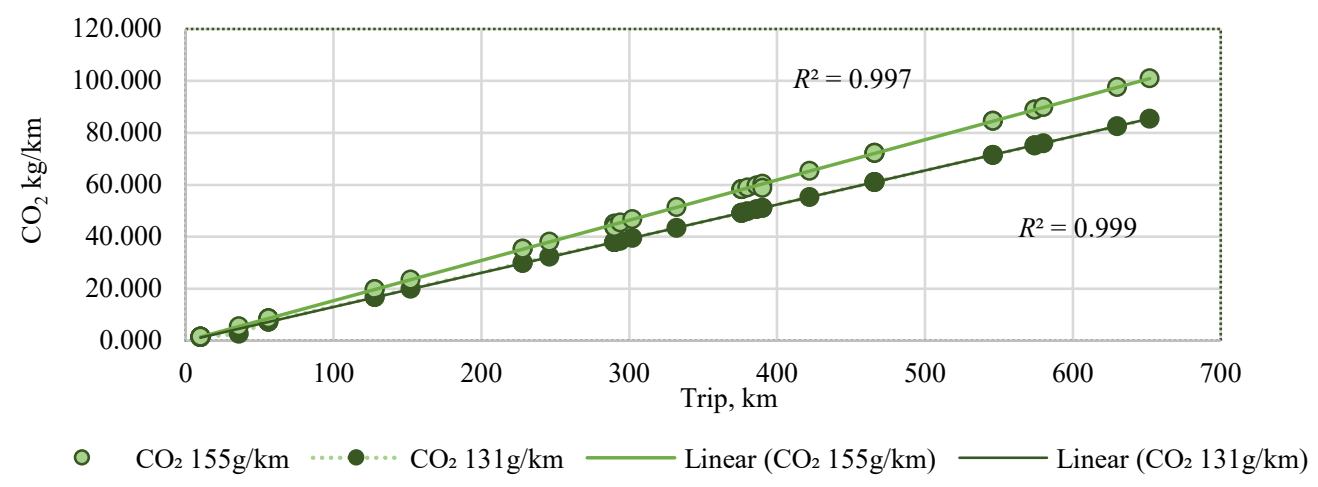

Fig. 5. Relationship between $\mathrm{CO}_{2}$ emissions and travel distance if emissions are $\mathrm{CO}_{2} 131 \mathrm{~g} / \mathrm{km}$ and $\mathrm{CO}_{2} 155 \mathrm{~g} / \mathrm{km}$.

Regression line Eq. (4) is as follows:

$$
y_{i}=0.156 x_{i}-0.1434,
$$

where

$y_{i} \quad$ Dependent variable, emissions $\mathrm{CO}_{2} 131 \mathrm{~g} / \mathrm{km}, \mathrm{kg}$;

$x_{i} \quad$ Independent (explanatory) variable, Trip, $\mathrm{km}$.

and Regression line Eq. (5) is as follows:

$$
y_{\mathrm{i}}=0.1314 x_{i}-0.1537,
$$

where

$y_{i} \quad$ Dependent variable, emissions $\mathrm{CO}_{2} 155 \mathrm{~g} / \mathrm{km}, \mathrm{kg}$;

$x_{i} \quad$ Independent (explanatory) variable, Trip, $\mathrm{km}$.

The correlation coefficient $r=0.997$ (Fig. 5) and $r=0.999$ indicates a strong positive correlation of emission $\mathrm{CO}_{2} 131 \mathrm{~g} / \mathrm{km}$ and $\mathrm{CO}_{2} 155 \mathrm{~g} / \mathrm{km}$. This explains in the scope of $99.7 \%$ and $99.9 \%$ the $\mathrm{CO}_{2}$ emissions and trip change with linear regression model. Since the F-test p-value (Tables 6 and 7) conclude that the model is statistically significant with the probability value of $99.7 \%$ and $99.9 \%$, the alternative hypothesis should be accepted that a linear connection exists between the trip and $\mathrm{CO}_{2}$ emissions $\left(\mathrm{CO}_{2} 131 \mathrm{~g} / \mathrm{km}\right.$ and $\left.\mathrm{CO}_{2} 155 \mathrm{~g} / \mathrm{km}\right)$.

TABLE 6. SUMmARY OF ANOVA MODEL EVOLUTION OF A LINEAR REGRESSION OF EMISSIONS $\mathrm{CO}_{2} 131 \mathrm{G} / \mathrm{KM}$ OVER A TRIP TO RECREATIONAL FISHING DESTINATIONS AT LATVIA'S WESTERN COAST OF THE BALTIC SEA

\begin{tabular}{llllll}
\hline $\begin{array}{l}\text { ANOVA } \\
\text { Model }\end{array}$ & Sum of squares & Df & Mean squares & $\boldsymbol{F}$ & Sig. \\
\hline Regression & 11628.262 & 1 & 11628.262 & $1.176 \mathrm{E}+12$ & $0.000^{\mathrm{b}}$ \\
Residual & 0.000 & 19 & 0.000 & - & - \\
\hline Total & 11628.262 & 20 & - & - & - \\
\hline
\end{tabular}

a. Dependent Variable: Emissions $\mathrm{CO}_{2} 131 \mathrm{~g} / \mathrm{km}$

b. Predictors: (Constant), Trip $(\mathrm{km})$ 
TABle 7. Summary of ANOVA MODEl EVOlution OF A LINEAR REGRESSION OF EMISSIONS $\mathrm{CO}_{2} 155$ G/KM OVER A TRIP TO RECREATIONAL FISHING DESTINATIONS AT LATVIA's WESTERN COAST OF THE BALTIC SEA

\begin{tabular}{llllll}
\hline $\begin{array}{l}\text { ANOVA }^{\mathbf{a}} \\
\text { Model }\end{array}$ & Sum of squares & Df & Mean squares & $\boldsymbol{F}$ & Sig. \\
\hline Regression & 11679.266 & 1 & 11679.266 & - & 0.000 \\
Residual & 0.000 & 19 & 0.000 & - & - \\
\hline Total & 11679.266 & 20 & - & - & - \\
\hline $\begin{array}{l}\text { a. Dependent Variable: Emissions } \mathrm{CO}_{2} 155 \mathrm{~g} / \mathrm{km} \\
\text { b. Predictors: (Constant), Trip (km) }\end{array}$
\end{tabular}

For the final model with the dependant variable - emissions at $\mathrm{CO}_{2} 155 \mathrm{~g} / \mathrm{km}$, influence statistics cannot be computed because the fit is perfect.

The Durbin-Watson coefficients $d_{\text {nov }}$ is 2.112 of Auxiliary regression of Model Summary (b) (of emission $\mathrm{CO}_{2} 131 \mathrm{~g} / \mathrm{km}$ ) if $d_{\text {nov }}>d_{\mathrm{Ua}}, 2.112>1.42$. The Durbin-Watson coefficients $d_{\text {nov }}$ is 1.672 of Auxiliary regression of Model Summary (b) (of emission $\mathrm{CO}_{2} 155 \mathrm{~g} / \mathrm{km}$ ), so the $1.672>1.42$. Values higher than 2 indicate a negative autocorrelation and therefore, there is statistical evidence that the terms causing error are not positively auto-correlated [40]. This indicates that the tested variables of significance can be used as indicators for predicting the process behaviour of interest.

In this research the VIF is 1.0 , which is a rather low value since the VIF $<3$, and can indicate a low correlation among variables under ideal conditions.

Research showed that there is a close positive correlation between three variables - both distance indicators and $\mathrm{CO}_{2}$ emission indicators. The relationship shows that there is a reversible feedback loop. The results approve the assumptions of U. Al-Mulali et al., as well as those of Katircioglu et al. (2014), that the growth of tourism industry increases $\mathrm{CO}_{2}$ emissions [41], [42]. It was proven in this research that the number of persons including the occupancy rates by travel have a significant impact, which is analysed in the next chapter.

\subsection{Determination of the Average Vehicle Occupancy Rates}

Analysis of the respondents shows that the distance travelled by (see section 2.2.2.) 50 respondents (car drivers), while the rest were passengers of whom part were also participating in recreational fishing, while others were family members including children. According to Eq. (2) and Eq. (3), the average vehicle occupancy rates $\left(A V O_{\text {veh } 1)}\right.$ and $\left(A V O_{\text {veh2 } 2)}\right.$ (Tables 8 and 9) were calculated.

Thus, the occupancy rates by travel purpose of recreational fishing per one vehicle were from 1 to 2 persons or on average 1.5 persons per one vehicle.

Data on the average vehicle occupancy rates and their tendencies chronologically are limited. According to the data from DRIEA, the occupancy rates for the light vehicles used for recreational tourism voyages in Europe are 1.6-2. [43]. In China this indicator is 1.7, while in the USA, the average occupancy rates were closer to 1.67 . When comparing occupancy rates by travel purpose in Europe, USA and China, the calculated indicator - total average occupancy rate.

(Table 8) 1.6 fits within the previously range, however this data indicates the situation in 2016 and present-day requirements for reduction of $\mathrm{CO}_{2}$ emissions in Europe incl., Latvia where, based on the authors opinion, it is a topical subject [44]. 
TABLE 8. VeHIClE OCCUPANCY RATES FOR VEHICLES OF VARIOUS CATEGORIES, NuMBER

\begin{tabular}{|c|c|c|c|c|c|}
\hline $\begin{array}{l}\text { Mode of } \\
\text { vehicle }\end{array}$ & $\begin{array}{l}\text { Modes of } \\
\text { number of } \\
\text { vehicles }\end{array}$ & $\begin{array}{l}\text { Number of } \\
\text { drivers }\end{array}$ & $\begin{array}{l}\text { Number of } \\
\text { passengers }\end{array}$ & $\begin{array}{l}\text { Total number of } \\
\text { real passengers* }\end{array}$ & $\begin{array}{l}\text { Average occupancy } \\
\text { rate } \\
\left(\text { AVO }_{\text {veh1 }}\right) \\
\text { (passenger/vehicle1) }\end{array}$ \\
\hline Car & 42 & 42 & 20 & 65 & 1.5 \\
\hline Motorhome & 2 & 2 & 6 & 6 & 2.0 \\
\hline Van & 1 & 1 & 1 & 2 & 2 \\
\hline Bicycle & 2 & 2 & 2 & 2 & 1 \\
\hline Bus & 2 & $\mathrm{X}$ & 3 & 3 & $\mathrm{X}$ \\
\hline Total & 52 & 50 & 28 & 78 & 1.6 \\
\hline
\end{tabular}

Notes: $\mathrm{X}$ - the phenomenon is not real; * - total number of real passengers (with driver).

According to Eq. 3, average vehicle occupancy rates were calculated and transferred to percentages (Table 9). The acquired results were in a range of $8.6 \%$ to $50 \%$, depending on the type of transport used, except for bicycles, which due to their specifics, would reach $100 \%$ $A V O_{\text {veh2. }}$ The average vehicle occupancy rate in Great Britain for cars/vans in 2016 was 55\%, while in certain countries, for example the Netherlands it was $91.6 \%$ - a high occupancy rate that had been achieved already in 2015 [45].

TABle 9. Vehicle OCCUPANCY RATES For Vehicle VARIES CATEGORIES, \%

\begin{tabular}{|c|c|c|c|c|c|c|}
\hline $\begin{array}{l}\text { Mode of } \\
\text { vehicle }\end{array}$ & $\begin{array}{l}\text { Modes of } \\
\text { number of } \\
\text { vehicles }\end{array}$ & $\begin{array}{l}\text { Total } \\
\text { number of } \\
\text { real } \\
\text { passengers } \\
*\end{array}$ & $\begin{array}{l}\text { Average occupancy } \\
\text { rate } \\
\text { (AVO veh1) } \\
\text { (passenger/vehicle) }\end{array}$ & $\begin{array}{l}\text { Maximum } \\
\text { number of } \\
\text { seats }\end{array}$ & $\begin{array}{l}\text { Total } \\
\text { estimated } \\
\text { number of } \\
\text { passengers }\end{array}$ & $\begin{array}{l}\text { Average } \\
\text { occupancy } \\
\text { rate } \\
\left(\mathbf{A V O}_{\text {veh2 }}\right), \\
\%\end{array}$ \\
\hline Car & 42 & 65 & 1.4 & 5 & 210 & 31 \\
\hline Motorhome & 2 & 6 & 2.0 & 6 & 8 & 50 \\
\hline Van & 1 & 2 & 2 & 8 & 8 & 25 \\
\hline Bicycle & 2 & 2 & 1 & 1 & 1 & 100 \\
\hline Bus & 2 & 3 & $X$ & 35 & 70 & 8.6 \\
\hline Total & 52 & 78 & 1.6 & $11 * *$ & 297 & 14.5 \\
\hline
\end{tabular}

Notes: $\mathrm{X}$ - the phenomenon is not real; * - total number of real passengers (with driver); ${ }^{* *}$ - total estimated number of passengers (average).

The average occupancy rate for cars is only $31 \%$, while for vans $-25 \%$ (Table 6 ). This means that not only the vehicles are used for travel to the tourism destinations in an inefficient way, but also that the environment is highly contaminated with emissions as a result. One might ask, why out of the respondents $75.5 \%$ of car drivers travel for recreational fishing alone? Similar tendency can be observed based on the $\mathrm{AVO}_{\text {veh2 }}-14.5 \%$. This is closely related to the individualistic traits of the modern person, which is a potential obstacle for collaboration possibilities, as noted by Kent [46]. There are different means for overcoming this problem: co-sharing of cars, thus also splitting the travel costs, or using cars with fewer emissions, but most importantly by changing the attitude and education of the people about the causes of global warming [47]. 


\subsection{Scenario and Analyses}

Based on acquired information, the transport emissions forecast allows to choose the optimum approach for minimizing the $\mathrm{CO}_{2}$ emissions. [36] The research included proposal scenarios while analysing the actual data acquired for finding possible salutations for reducing the emissions within the recreation fishing tourism trips to the Kurzeme coastline. Taking into account that in $73 \%$ of cases cars were used as the primary means of transport to reach the recreational fishing destination, further attention was focused on the type of vehicle used. In previous research three different types of reasons for $\mathrm{CO}_{2}$ emissions were determined:

- $\mathrm{CO}_{2}$ emissions are dependent on the first registration year of the car i.e., the age of the car (Table 3.);

- $\mathrm{CO}_{2}$ emissions are dependent on the road path to the destination of recreational fishing and the $\mathrm{CO}_{2}$ emissions per km of the vehicle (Fig. 5 and Fig. 6.);

- $\mathrm{CO}_{2}$ emissions are dependent on the number of persons riding in a given vehicle.

Based on these conclusions, authors propose three scenarios:

1. First scenario - replacing the current light weight vehicles with ones, which are in line with EU regulations at $95 \mathrm{gCO}_{2} / \mathrm{km}$.

2. Second scenario - the light vehicle (car) occupancy rate reaches the peak at $100 \%$ and $60 \%$.

3. Third scenario - extrapolation of the recreational fishing travel indicates the optimum mean passenger number to $\mathrm{CO}_{2}$ emissions, when using cars with $95 \mathrm{gCO}_{2} / \mathrm{km}$ with $60 \%$ average vehicle occupancy rates.

The scenarios will help answer the following questions:

- By what amount would the $\mathrm{CO}_{2}$ emissions decrease if the respondents would use new transport vehicles, according to EU Regulation (EU) 2019/631 from 2020 [48], when the EU fleet-wide average emission target for new cars will be $95 \mathrm{gCO}_{2} / \mathrm{km}$ ?

- By what amount would the $\mathrm{CO}_{2}$ emissions be reduced per one passenger if $100 \%$ or $60 \%$ of the seats would be occupied?

- By what amount would the $\mathrm{CO}_{2}$ emissions be reduced per passenger when travelling to the recreational fishing destinations per year, compared to the values estimated within the research, if cars with $95 \mathrm{gCO}_{2} / \mathrm{km}$ and $60 \%$ average occupancy rate would be used?

The three scenarios of the study are as follows:

- First scenario:

When calculating, one would consider the new car emission regulations, according to EU Regulation 2019/631 [37] $\mathrm{CO}_{2} 95 \mathrm{~g} / \mathrm{km}$ with the light passenger vehicles which emissions $\mathrm{CO}_{2}$ stand at $156 \mathrm{~g} / \mathrm{km}$, shows that it is possible to reach by $684.49 \mathrm{~kg} \mathrm{CO}_{2}$ less emissions, with emission level at $\mathrm{CO}_{2} 147 \mathrm{~g} / \mathrm{km}$ - by $\mathrm{CO}_{2} 847 \mathrm{~g} / \mathrm{km}$ fewer, but with emissions $131 \mathrm{~g} / \mathrm{km}$ - by $570.84 \mathrm{~kg}$ fewer $\mathrm{CO}_{2}$ emissions (Fig. 7). 


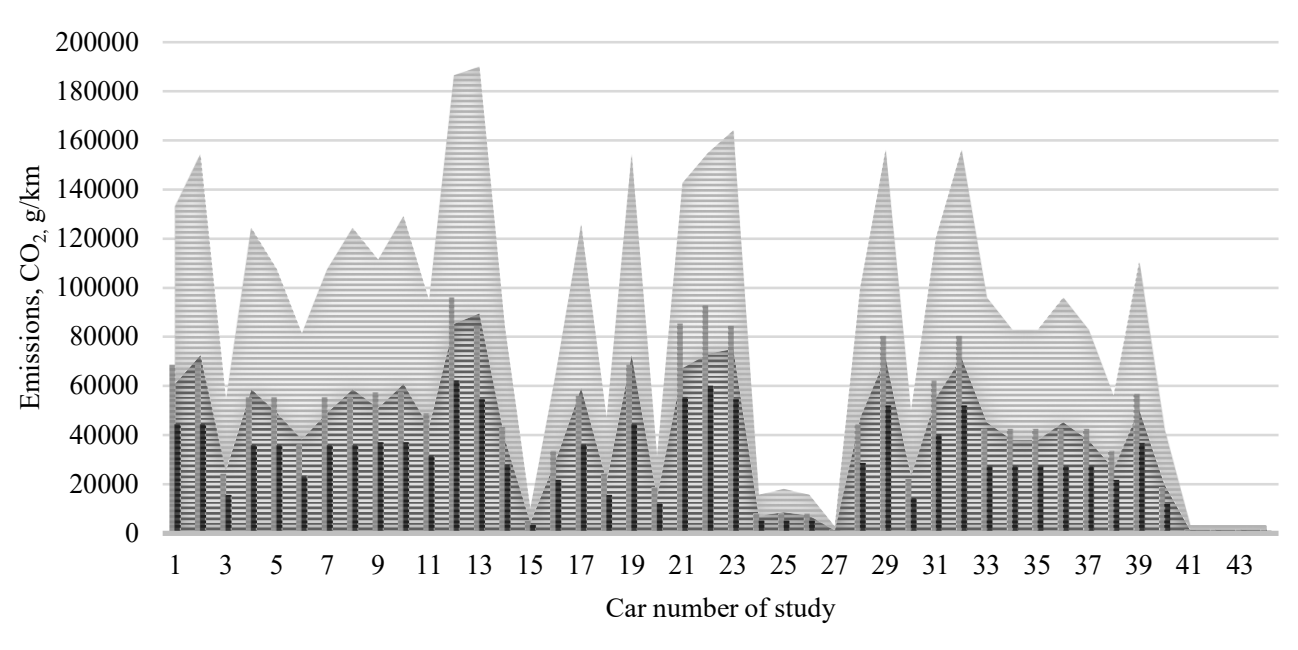

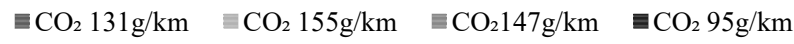

Fig. 7. Real $\mathrm{CO}_{2}$ emissions of a journey for recreational fishing in comparison with hypothetical compliance with [37].

- Second scenario:

Total estimated number of passengers is 225 , while in reality there are 65 passengers (Table 6). It was estimated that the actual emissions per one passenger at the car emission rate $\mathrm{CO}_{2} 156 \mathrm{~g} / \mathrm{km}$ were $28.02 \mathrm{kgCO}_{2}$, while at $\mathrm{CO}_{2} 147 \mathrm{~g} / \mathrm{km}$ the emissions were $32.27 \mathrm{kgCO}_{2}$, but at the emission rate of $\mathrm{CO}_{2} 131 \mathrm{~g} / \mathrm{km}$ it was $29.77 \mathrm{kgCO}_{2}$. However, in a scenario, when all of the vehicle seats are taken, the amount of emissions per passenger would be $\mathrm{CO}_{2} 8.1 \mathrm{~kg}, 9.33 \mathrm{~kg}$ and $8.6 \mathrm{~kg}$ correspondingly, but in this case, if the emissions were $\mathrm{CO}_{2} 95 \mathrm{~g} / \mathrm{km}$ per car, then $5.56 \mathrm{~kg} \mathrm{CO}_{2}$ would be emitted. Certainly, $100 \%$ vehicle occupancy rate is only possible in theory and the real data would be lower, while the average occupancy rates $\left(A V O_{\text {veh } 1}\right)$ are 1.4 (Table 5). In reality, the upper level of transport occupancy is assumed to be $60 \%$ [49], which means that the average occupancy rates should be two and more passengers per car. The $\mathrm{CO}_{2}$ emissions would reduce per one passenger if $100 \%, 60 \%$ of the seats would be occupied, depending on the number of seats per vehicle and based on the emissions $\mathrm{CO}_{2} 156 \mathrm{~g} / \mathrm{km}, \mathrm{CO}_{2} 147 \mathrm{~g} / \mathrm{km}$ and $\mathrm{CO}_{2} 131 \mathrm{~g} / \mathrm{km}$ would correspondingly create $\mathrm{CO}_{2} 6.77 \mathrm{~kg}, \mathrm{CO}_{2} 5.01 \mathrm{~kg}$ and $\mathrm{CO}_{2} 5.4 \mathrm{~kg}$.

- Third scenario:

The research revealed that a single respondent who has a passenger car, annually covers 1 to 120 trips (Fig. 8) to recreational fishing destinations, while the mean is 22 , and the median is 10 trips correspondingly. 


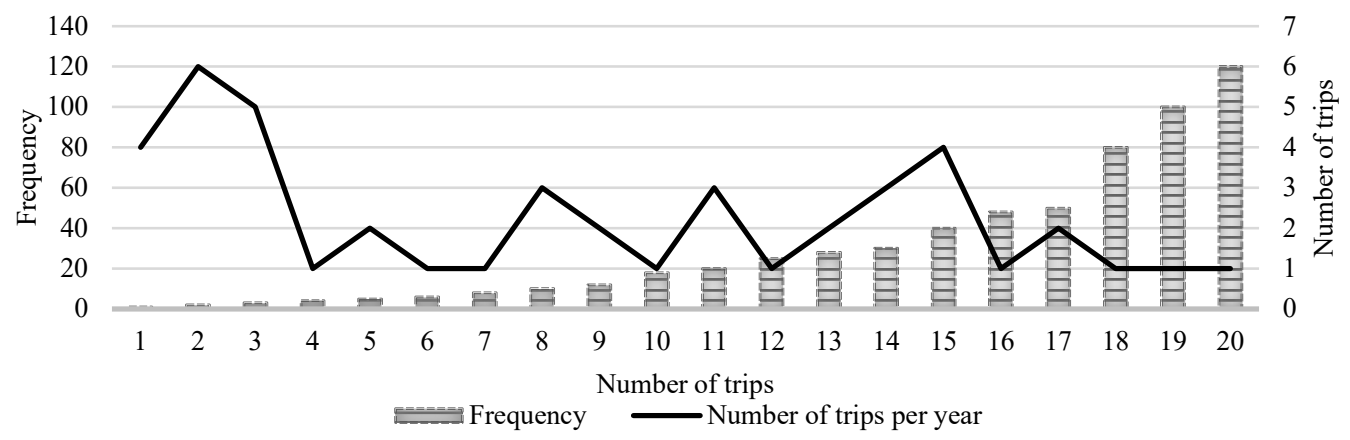

Fig. 8. Number of trips and frequency per year to Latvia's Western coast of the Baltic Sea for recreational fishing.

When carrying out trips to recreational fishing destinations per year per passenger, if a car with $95 \mathrm{gCO}_{2} / \mathrm{km}$ and a $60 \%$ average vehicle occupancy rate is used, then the following $\mathrm{CO}_{2}$ emission reduction dependent on the car emissions $\mathrm{CO}_{2} 156 \mathrm{~g} / \mathrm{km}, \mathrm{CO}_{2} 147 \mathrm{~g} / \mathrm{km}$ and $\mathrm{CO}_{2} 131 \mathrm{~g} / \mathrm{km}$, is possible with the cumulative emission reduction at $297.7 \mathrm{~kg}, 322.7 \mathrm{~kg}$ and $280.2 \mathrm{~kg}$ accordingly.

Small changes to the car utilization models create significant $\mathrm{CO}_{2}$ emission reduction. The co-sharing of cars could help reduce vehicle emissions. As it was proven by other research projects, the reduction of emissions through more effective use can give similar effects to a limited electrification of the car fleet [50]. In these conditions, the Hungarian case should be noted, a country which faces significant global warming caused effects more significant that the rest of Europe. Hungary has decided on reaching the $2030 \mathrm{CO}_{2}$ emission goals and one of the goals is to increase the number of passengers per car [51]. Meanwhile, a more intensive use of car fleet increases the depreciation of the cars and it can increase the service costs. However, in the recreational fishing areas of Latvia's Western Baltic Sea coast the public transport network is inadequate for tourism travel purposes, partly due to sparse population density. As a result, the authors see the car seat sharing as a possible realistic path for reducing emissions, also through educating the population about the reduction of emissions.

\section{Conclusion}

Recreational fishing within the Baltic Sea region is popular in all countries, including Latvia, whilst providing millions of people with enjoyment, kinship and food. Development of recreational fishing tourism creates opportunities for creation of new types of businesses, thus strengthening the national economy, improving infrastructure, and an environment friendly attitude towards the climate. The Baltic Sea region has the potential to become one of the leading regions in the world in terms of sustainable development and Latvia already has substantial achievements in terms of reduction of $\mathrm{CO}_{2}$ emissions. However, further development of recreational fishing tourism in Latvia, Kurzeme region western coast of Baltic Sea, is connected to intensification of fossil $\mathrm{CO}_{2}$ emissions, most profoundly in the transport sector.

When analysing the actual situation on trips to the recreational fishing destination it was determined:

1. The most distant of 14 destinations within Latvia is located $326 \mathrm{~km}$ away on average 
from any given point where survey was conducted, while outside of Latvia - on $1756 \mathrm{~km}$ distance. Altogether, in order to reach the recreational fishing destination (including return trip), the respondents travelled on average $346.86 \mathrm{~km}$ and in total travelled $22546 \mathrm{~km}$ with $5.796 \mathrm{~kg} \mathrm{CO}$ emissions;

2. That $\mathrm{CO}_{2}$ emissions were dependant on the age of the cars, whereby cars produced between 2006-2007 had higher $\mathrm{CO}_{2}$ emissions of 156-175 g/ $\mathrm{km}$, and the majority of cars (produced within the 2009-2016 period) had lower emissions of $131-155 \mathrm{~g} / \mathrm{km}$ and also travelled a furthest distance and therefore produced most of the emissions $\mathrm{CO}_{2} 1938.565 \mathrm{~kg}$ emissions;

3. Emissions of such passenger transport types as van and motorhome had multiple times higher amounts of emissions than the cars, and the $\mathrm{CO}_{2}$ emissions for these types totalled $2007.166 \mathrm{CO}_{2} \mathrm{~kg}$, which in total is close to emissions produced by all of the cars and they are highly inefficient in terms of climate impact;

4. There is a close positive relationship between the travelled distance and $\mathrm{CO}_{2}$ emissions of a given type of vehicle have a close positive linear correlation $\mathrm{r}=0.997$ and $\mathrm{r}=$ 0.999 with a determination coefficient 0.96 and 0.96 , which with $99.7 \%$ and $99.9 \%$ explains the $\mathrm{CO}_{2}$ emissions and trip change with a linear regression model. This means that when pursuing closer trips, there would be a lower emission amount and that would affect climate change less negatively;

5. Vehicle occupation rates for vehicles of various categories by recreational fishing on Latvian Western coast of Baltic Sea is 1.5, but in terms of percentage the vehicle occupation of car is $28.9 \%$, for motorhome $50 \%$ and for vans is $25 \%$. The research showed that vehicle occupation rates are insufficient among all types of vehicles.

While analysing three climate impact scenarios for analysing $\mathrm{CO}_{2}$ emissions reduction perspectives, it was determined that:

1. When substituting the used cars with less polluting ones, at $\mathrm{CO}_{2} 155 \mathrm{~g} / \mathrm{km}$, it was possible to reduce $\mathrm{CO}_{2}$ emissions by $684.49 \mathrm{~kg}$ per year, with emissions $\mathrm{CO}_{2} 147 \mathrm{~g} / \mathrm{km}$ - by $\mathrm{CO}_{2} 847 \mathrm{~kg}$ per year, but with emissions $131 \mathrm{~g} / \mathrm{km}$ - by $570.84 \mathrm{~kg}$ per year;

2. When forecasting $100 \%$ occupancy rates for light vehicles per single respondent, the reduction of emissions would be possible depending on the emissions rate $\mathrm{CO}_{2} 155 \mathrm{~g} / \mathrm{km}, \mathrm{CO}_{2} 147 \mathrm{~g} / \mathrm{km}$ and $\mathrm{CO}_{2} 131 \mathrm{~g} / \mathrm{km}$, reducing accordingly by $\mathrm{CO}_{2}$ $6.77 \mathrm{~kg}, \mathrm{CO}_{2} 5.01 \mathrm{~kg}$ un $\mathrm{CO}_{2} 5.4 \mathrm{~kg}$;

3. When travelling to fishing destinations annually per passenger, with car emissions of $95 \mathrm{gCO}_{2} / \mathrm{km}$ and with a $60 \%$ average vehicle occupancy rates, it was determined that reduction of $\mathrm{CO}_{2}$ emissions is possible depending on car emissions of $\mathrm{CO}_{2} 155 \mathrm{~g} / \mathrm{km}$, $\mathrm{CO}_{2} 147 \mathrm{~g} / \mathrm{km}$ un $\mathrm{CO}_{2} 131 \mathrm{~g} / \mathrm{km}$, totalling reductions of $297.7 \mathrm{~kg}, 322.7 \mathrm{~kg}$ and $280.2 \mathrm{~kg}$ correspondingly.

More intense car-sharing practices would increase vehicle occupation rates and the use of newer models of cars with reduced $\mathrm{CO}_{2}$ emissions would make it possible to reduce the emissions of transport vehicles and their impact on climate change when travelling to recreational fishing areas in Latvia's Western coast of the Baltic Sea, the accessibility to which is limited due to low availability of public transport.

\section{ACKNOWLEDGEMENT}

Thanks to the Kurzeme Planning region coordinator Zane Gaile for allowing the use of data from the project RETROUT Nr. R065. 


\section{REFERENCES}

[1] Gössling S., Buckley, R. Carbon labels in tourism: Persuasive communication? Journal of Cleaner Production 2016:111:358-369. https://doi.org/10.1016/j.jclepro.2014.08.067

[2] Facanha C., Blumberg K., Miller J. Global Transportation Energy and Climate Roadmap. Washington: ICCT, 2012.

[3] Communication from the Commission to the European Parliament, the Council, the European Economic and Social Committee and the Committee of the Regions - A European Strategy for the Mobility of Small Emissions (COM(2016) final). Brussels: European Commission, 2016.

[4] Crippa M., et al. Fossil CO2 and GHG emissions of all world countries - 2019 Report. Luxembourg: Publications Office of the European Union, 2019. https://doi.org/10.2760/687800

[5] CSB. Foreign travellers in Latvia. Characteristics of non-resident travellers; 2000, 2007-2018. Tourism in Latvia. Riga: CSB, 2019.

[6] CSB. Number of Latvian resident travellers going on same-day or overnight on recreational and other private trips around Latvia or abroad; 2015-2018. Recreational and business trips of Latvian population in Latvia and abroad. Tourism in Latvia. Riga: CSB, 2019.

[7] CSB. Same-day trips around Latvia by destination; 2017-2018. Recreational and business trips of Latvian population in Latvia and abroad. Tourism in Latvia. Riga: CSB, 2019.

[8] CSB. Mode of transport used during overnight trips around Latvia 2018. Recreational and business trips of Latvian population in Latvia and abroad. Tourism in Latvia. Riga: CSB, 2019.

[9] CSB. Mode of transport used during some-day trips around Latvia 2018. Recreational and business trips of Latvian population in Latvia and abroad. Tourism in Latvia. Riga: CSB, 2019.

[10] Kurzemes plānošanas regions. Projekta RETROUT tiek izstrādāts plans Baltijas jūras piekrastes kā sporta un atpūtas makšķerešanas tūrisma galamēṛkia veidošanai. (Planning regions of Kurzeme. Project RETROUT aimed at developing a plan of Baltic Sea coastline as a sport, leisure and recreational fishing destination). [Online]. [Accessed 13.10.2019]. Available: https://www.kurzemesregions.lv/projekta-retrout-tiek-izstradats-plans-baltijas-juras-piekrastes-ka-sportaun-atputas-makskeresanas-turisma-galamerka-veidosanai/ (in Latvian)

[11] Chatterton T. J., et al. Understanding how transport choices are affected by the environment and health: Views expressed in a study on the use of carbon calculators. Public Health 2009:123(1):45-49. https://doi.org/0.1016/j.puhe.2008.10.022

[12] De Nazelle A., et al. Short trips: An opportunity for reducing mobile-source emissions? Transportation Research: Part D: Transport Environment 2010:15:451-457. https://doi.org/10.1016/j.trd.2010.04.012

[13] Goodman A., Brand C., Ogilvie D. Associations of health, physical activity and weight status with motorised travel and transport carbon dioxide emissions: a cross-sectional, observational study. Environ Health 2012:11:52. https://doi.org/10.1186/1476-069X-11-52

[14] Brand C., et al. Associations of individual, household and environmental characteristics with carbon dioxide emissions from motorised passenger travel. Applied Energy 2013:104:158-169.

https://doi.org/10.1016/j.apenergy.2012.11.001

[15] Frank L. D., et al. Carbonless footprints: promoting health and climate stabilization through active transportation. Preventive Medicine 2010:50:99-105. https://doi.org/10.1016/j.ypmed.2009.09.025

[16] Frank L. D., et al. Stepping towards causation: do built environments or neighborhood and travel preferences explain physical activity, driving, and obesity? Social Science \& Medicine 2007:65:1898-1914. https://doi.org/10.1016/j.socscimed.2007.05.053

[17] World Tourism Organization and International Transport Forum Transport-related $\mathrm{CO}_{2}$ Emissions of the Tourism Sector - Modelling Results. UNWTO, Madrid. Spain, 2019. https://doi.org/10.18111/9789284416660

[18] Bryman A. Integrating quantitative and qualitative research: How is it done? Qualitative Research 2006:6(1):97-113. https://doi.org/10.1177/1468794106058877

[19] Hanpattanakita P., et al. CO2 Emission and Reduction of Tourist Transportation at Kok Mak Island, Thailand. Chemical Engineering Transactions 2018:63:37-42. https://doi.org/10.3303/CET1863007

[20] Adhi R. P. Top-Down and Bottom-Up Method on Measuring $\mathrm{CO}_{2}$ Emission from Road-Based Transportation System (Case Study: Entire Fuel Consumption, Bus Rapid Transit, and Highway in Jakarta, Indonesia). Journal Teknologi Lingkungan 2018:19:249-258. https://doi.org/10.29122/jtl.v19i2.2840

[21] Eurostat. Coastal region definition. (2017) [Online]. [Accessed 13.12.2019]. Available: https://ec.europa.eu/eurostat/statistics-explained/index.php/Glossary:Coastal_region

[22] Grizane T., et al. Emissions of carbon Dioxide $\left(\mathrm{CO}_{2}\right)$ and Growth the Tourism Industry: Case study of Latvia. Proceedings of the 2019 International Conference on Economic Science for Rural Development 2019:347354. https://doi.org/10.22616/ESRD.2019.141

[23] Grizane T., Jurgelane-Kaldava I. Tourist Transportation Generated Carbon Dioxide (CO2) Emissions in Latvia. Environmental and Climate Technologies 2019:23(3):274-292. https://doi.org/10.2478/rtuect-2019-0095 
[24] CSDD Rokasgrāmatas par vidējo degvielas patēriṇu un $\mathrm{CO}_{2}$ izplūdi. (Road Traffic Safety Directorate (CSDD). Manual on the average fuel consumption and $\mathrm{CO}_{2}$ emissions). [Online]. [Accessed 13.12.2019]. Available: https://www.csdd.lv/videjais-degvielas-paterins/rokasgramatas-par-videjo-degvielas-paterinu-un-co2-izpludi (in Latvian)

[25] Monitoring of $\mathrm{CO}_{2}$ emissions from new vans - Regulation (EU) 510/2011 provided by European Environment Agency (EEA) [Online]. [Accessed 03.01.2020]. Available: https://www.eea.europa.eu/data-andmaps/daviz/average-carbon-dioxide-emissions-from-1\#tab-chart_1

[26] European Environment Agency. Monitoring $\mathrm{CO}_{2}$ emissions from passenger cars and vans in 2013. Technical report. Luxembourg: Publications Office of the European Union, 2014. https://doi.org/10.2800/23352

[27] Larsson J., Kamb A. Travel and climate. Gothenburg: Chalmers University of Technology, 2019.

[28] Carbon Independent Org. Emissions from bus travel [Online]. [Accessed 15.01.2020]. https://www.carbonindependent.org/20.html

[29] Cairns S., et al. Smarter choices: Assessing the potential to achieve traffic reduction using 'soft measures'. Transport Reviews 2008:28:593-618.

[30] Petrunoff N., et al. Carrots and sticks vs carrots: comparing approaches to workplace travel plans using disincentives for driving and incentives for active travel. Journal of Transport \& Health 2015:2(4):563-567. https://doi.org/10.1016/j.jth.2015.06.007

[31] Scottish Government. Going Smarter. Final Report-Monitoring and Evaluation of the Smarter Choices, Smarter Places Programme, Edinburgh: The Scottish Government, 2013.

[32] DRIEA. Enquête globale transport. Motorisation et usage de la voiture en Île-de-France. (Global transport survey. Motorization and car usage in Île-de-France.) Paris: DRIEA, 2013. (in French)

[33] Boutueil V. How full are the vehicles? A glance at vehicle occupancy rates. Towards a sustainable mobility system: Leveraging corporate car fleets to foster innovations. Architecture, spatial planning. Paris: University of Paris-Est, 2015.

[34] Agarwal A. Vehicle Occupancy. A Comparison of Weekend and Weekday Travel Behaviour Characteristics in Urban Areas. USA: University of South Florida, 2004.

[35] European Environment Agency. Occupancy rates. [Online]. [Accessed 13.01.2020]. https://www.eea.europa.eu/publications/ENVISSUENo12/page029.html

[36] Barisa A., Rosa M. Scenario analysis of $\mathrm{CO} 2$ emission reduction potential in road transport sector in Latvia. Energy Procedia 2018:147:86-95. https://doi.org/10.1016/j.egypro.2018.07.036

[37] Regulation (EU) 2019/631 of the European Parliament and of the Council of 17 April 2019 setting CO2 emission performance standards for new passenger cars and for new light commercial vehicles, and repealing Regulations (EC) No 443/2009 and (EU) No 510/2011 (Text with EEA relevance.). Official Journal of the European Union 2019:L 111/13

[38] Al-Mulali U., Fereidouni H. G., Mohammed A. H. The effect of tourism arrival on CO2 emissions from transportation sector. Anatolia 2015:26(2):230-243. https://doi.org/10.1080/13032917.2014.934701

[39] Autoalan Tiedotuskeskus (AuT). Average age of passenger cars in some European countries. [Online]. [Accessed 12.01.2020]. Available:

http://www.aut.fi/en/statistics/international_statistics/average_age_of_passenger_cars_in_some_european_co untries

[40] Lee J. W., Brahmasrene T. Investigating the Influence of Tourism on Economic Growth and Carbon Emissions: Evidence from Panel Analysis of the European Union. Tourism Management 2013:38:69-76. https://doi.org/10.1016/j.tourman.2013.02.016

[41] Al-Mulali U., et al. Estimating the tourism-led growth hypothesis: a case study of the Middle East countries. An International Journal of Tourism and Hospitality Research 2014:25(2):290-298. https://doi.org/10.1080/13032917.2013.843467

[42] Katircioglu S. T., Feridun M., Kilinc C. Estimating tourism-induced energy consumption and CO2 emissions: the case of Cyprus. Renewable and Sustainable Energy Reviews 2014:29:634-640. https://doi.org/10.1016/j.rser.2013.09.004

[43] Cox. W. Average chinece car travels as much as American car. 2020 New Geography [Online]. [Accessed 14.01.2020]. Available: https://www.newgeography.com/content/006420-average-chinese-car-travels-much-american-car

[44] European Environment Agency. Occupancy rates [Online]. [Accessed 14.01.2020]. Available: https://www.eea.europa.eu/publications/ENVISSUENo12/page029.html

[45] Jeekel H. Inclusive Transport: Fighting Involuntary Transport Disadvantages. Amsterdam: Elsevier Inc., 2019.

[46] Kent J. Secured by Automobility: Why Does the private car continue to dominante transport practices? Sydney: University of New South Wales, 2013.

[47] Kent J., Dowling R. The future of paratransit and DRT: Introducing cars on demand. Paratransit: Shaping the Flexible Transport Future (Transport and Sustainability), vol 8. pp. 391-412, Emerald Group Publishing, 2016. https://doi.org/10.1108/S2044-994120160000008019

[48] Regulation (EU) 2019/631 of the European Parliament and of the Council of 17 April 2019 setting CO2 emission performance standards for new passenger cars and for new light commercial vehicles, and repealing Regulations (EC) 
No 443/2009 and (EU) No 510/2011 (Text with EEA relevance.). Official Journal of the European Union 2019:L 111/13

[49] Passenger transport - increase in vehicle occupancy. Vehicle capacity and occupancy for Level1 to 4. [Online]. [Accessed 13.01.2020]. Available:

http://sa2050pathways.environment.gov.za/assets/onepage/za_vehicle_occupancy.pdf

[50] Serrenho A. C., Allwood J. M. Material Stock Demographics: Cars in Great Britain. Environ. Sci. Technol. 2016:50(6):3002-3009. https://doi.org/10.1021/acs.est.5b05012

[51] Transport and Environment. Emission Reduction Strategies for the Transport Sector in Hungary. Brussels: Belgium, 2018. 